\title{
T. S. Eliot and Others: The (More or Less) Definitive History and Origin of the Term "Objective Correlative"
}

\section{Dominic Griffiths}

To cite this article: Dominic Griffiths (2018) T. S. Eliot and Others: The (More or Less) Definitive History and Origin of the Term "Objective Correlative", English Studies, 99:6, 642-660, DOI: 10.1080/0013838X.2018.1497822

To link to this article: https://doi.org/10.1080/0013838X.2018.1497822

曲 Published online: 11 Sep 2018.

Submit your article to this journal $\widetilde{ }$

山 Article views: 10

View Crossmark data $\complement$ 


\title{
T. S. Eliot and Others: The (More or Less) Definitive History and Origin of the Term "Objective Correlative"
}

\author{
Dominic Griffiths \\ Department of Philosophy, University of Johannesburg, Johannesburg, South Africa
}

\begin{abstract}
This paper draws together as many as possible of the clues and pieces of the puzzle surrounding T. S. Eliot's "infamous" literary term "objective correlative". Many different scholars have claimed many different sources for the term, in Pound, Whitman, Baudelaire, Washington Allston, Santayana, Husserl, Nietzsche, Newman, Walter Pater, Coleridge, Russell, Bradley, Bergson, Bosanquet, Schopenhauer and Arnold. This paper aims to rewrite this list by surveying those individuals who, in different ways, either offer the truest claim to being the source of the term, or contributed the most to Eliot's development of it: Allston, Husserl, Bradley and Bergson. What the paper will argue is that Eliot's possible inspiration for the term is more indebted to the idealist tradition, and Bergson's aesthetic development of it, than to the phenomenology of Husserl.
\end{abstract}

This paper, in the spirit of intellectual history, draws together as many as possible of the clues and pieces of the puzzle surrounding T. S. Eliot's "infamous" literary term "objective correlative". ${ }^{1}$ Many different scholars have claimed many different sources for the term, in Pound, Whitman, Baudelaire, Washington Allston, Santayana, Husserl, Nietzsche, Newman, Walter Pater, Coleridge, Russell, Bradley, Bergson, Bosanquet, Schopenhauer and Arnold. ${ }^{2}$ This piece will rewrite this list by surveying those individuals who, in different ways, either offer the truest claim to being the source of the term, or contributed the most to Eliot's development of it: Allston, Husserl, Bradley and Bergson. On the way, some of the strengths and weaknesses of the term will be discussed. What this survey shows, with fresh clarity, is that a single direct source for the term "objective correlative" is not to be found. Rather, it was born out of a trans-Atlantic philosophical conversation about the nature of objects, a conversation with which Eliot was well acquainted. It was

\footnotetext{
CONTACT Dominic Griffiths Dominic.griffiths@wits.ac.za

"The term is "infamous" because it is indelibly associated with "one of the most critical documents of the 20th century" namely "Hamlet and His Problems". Eliot takes "the opportunity to pontificate on finding a serious flaw in one of the world's greatest tragic plays, and he not only gets away with it but enhances his own reputation and credentials as a critical intellect in the process". See Murphy, 163, 247. For examples where the term is described as "infamous" see Wood; Hartman, 133; Sayeau, 211.

${ }^{2}$ While this paper aims to be as exhaustive and comprehensible as possible in its examination of the major influences and sources of Eliot's "objective correlative", some of the minor and less significant figures will not be mentioned. Many can be sourced by consulting Frank, 317, n.1. For John Henry Newman see Cowley. For Nietzsche see Lees. For Walter Pater see DeLaura. For Santayana see McElderry. For Coleridge consult Di Pasquale. For Schopenhauer see Virkar-Yates. Further to this see also editorial note 15 for "Hamlet" in Eliot, Complete Prose, vol. 2, 128, n.15.
} 
from this philosophical familiarity that he drew in forming his own aesthetic, literary ideas of criticism. While there are surface similarities evident in the various potential influences on Eliot's term these can disguise what are, in fact, pronounced differences in the idealist and phenomenological approaches to understanding the nature of objects. As this paper will show, Eliot's "objective correlative" is indebted more to the idealist tradition, and Bergson's influence, than to the complexities of Husserlian phenomenology.

Frank Kermode, in his masterful introduction to the Selected Prose of T. S. Eliot (1975), describes the term "objective correlative" as a phrase that suffers from "imperfect articulation", theorised in one of Eliot's "least impressive essays". ${ }^{3}$ The essay in question is "Hamlet and His Problems", which was written in 1919 and republished in a collection of Eliot's essays titled The Sacred Wood: Essays on Poetry \& Criticism (1920). ${ }^{4}$ In the essay Eliot writes:

The only way of expressing emotion in the form of art is by finding an "objective correlative"; in other words, a set of objects, a situation, a chain of events which shall be the formula of that particular emotion; such that when the external facts, which must terminate in sensory experience, are given, the emotion is immediately evoked. ${ }^{5}$

Eliot develops the term to criticise Hamlet, which he considered a failure because Shakespeare did not provide enough content in the play to generate the horror in the audience that Hamlet, the character, experiences in himself. "Hamlet", Eliot writes, "is full of some stuff that the writer could not drag to light, contemplate, or manipulate into art. And when we search for this feeling, we find it ... very difficult to localize". ${ }^{6}$ In other words, Hamlet is a failure because it lacks an objective correlative. Eliot writes that "Hamlet (the man) is dominated by an emotion which is inexpressible, because it is in excess of the facts as they appear". ${ }^{7}$ Eliot locates this excess of emotion in Hamlet's reaction to his mother Gertrude. Hamlet is disgusted by her but his disgust envelopes and exceeds her as a character. It is thus a feeling Hamlet cannot understand, and so neither can we the audience. The problem, Eliot contends, is that Gertrude is not an adequate equivalent to represent this disgust. Furthermore there is nothing in the play that Shakespeare can do to express this reaction. Eliot points out that in successful tragedies you find this "exact equivalence", for example,

you will find that the state of mind of Lady Macbeth walking in her sleep has been communicated to you by a skilful accumulation of imagined sensory impressions; the words of Macbeth on hearing of his wife's death strike us as if, given the sequence of events, these words were automatically released by the last event in the series. The artistic "inevitability" lies in this complete adequacy of the external to the emotion; and this is precisely what is deficient in Hamlet. ${ }^{8}$

This criticism of Hamlet has struck many readers as odd. In the words of Bradley Greenberg, Eliot produced in his version of the objective correlative a "conceptual formulation that has proved difficult and often unwieldy for criticism". 9 Kermode, as we know,

\footnotetext{
${ }^{3}$ Kermode, 16.

${ }^{4}$ Eliot, Sacred Wood, 100. "Hamlet and His Problems" first appeared in the Athenaeum 26 September 1919, 940-1, see Gallup, 84.

${ }^{5}$ Eliot, The Sacred Wood, 92.

${ }^{6}$ Ibid., 91.

${ }^{7}$ Ibid., 92

8 Ibid.

${ }^{9}$ Greenburg, 217.
} 
describes it as an idea imperfectly articulated, and, as another critic notes, it "collapses very quickly under analysis". ${ }^{10}$ Certainly Eliot, a young and promising man of letters (he was 32 when The Sacred Wood, his first volume of criticism, was published) wanted to generate some controversy by criticising what many would call one of the greatest artworks in existence. Later in life Eliot admitted as much, stating in his lecture "To Criticize the Critic", delivered in 1961, that in his Hamlet essay he was not "altogether guiltless of trailing my coat: I was at the time hand-in-glove with that gallant controversialist, J. M. Robertson". ${ }^{11}$ He adds, presciently, that if his phrases are "given consideration in a century hence, it will be only in their historical context". ${ }^{12}$ While we might charitably argue that the term "objective correlative" had some merit before it was surpassed by more sophisticated literary theories that appeared subsequently, Eliot's application of it to Hamlet to explain why the play is a failure is hardly convincing. Nonetheless, his dramatic examples go some way towards demonstrating the meaning of "objective correlative": essentially, a great artwork should both convey and elicit the necessary emotional response from the viewer. However, the term in this literary sense is far more "impressionistic" than "rigorous". 13

Aside, then, from what one of the twentieth century's greatest poets actually meant in this important and somewhat puzzling essay, what is and remains a question is where the term originates. Did Eliot really create the term himself ex nihilo? Or are there other thinkers whose use of the term preceded and possibly inspired Eliot's own? This essay aims reinvestigate the issue by discussing the different individuals who have developed a term similar to Eliot's and whose ideas Eliot encountered.

\section{I.}

The first clue to the original source of the term is given by Eliot himself, with a tone of mild incredulity, in his 1956 preface to Essays on Elizabethan Drama, a reprinting of works from his earlier volumes, including The Sacred Wood, Selected Essays (1932) and Elizabethan Essays (1934). ${ }^{14}$ In this preface Eliot writes that re-reading some of his early essays, including "Hamlet and His Problems", he is "embarrassed ... by their callowness, and by a facility of unqualified assertion which verges, here and there, on impudence". ${ }^{15}$ He goes on to write that the "Hamlet, of course, ha[s] been kept afloat all these years by the success of the phrase 'objective correlative' - a phrase which, I am now told, is not even my own but was first used by Washington Alston [sic]". ${ }^{16}$

Washington Allston (1779-1843) was an American, a New England painter and writer who died some forty-five years before Eliot was born. Allston came from Cambridge, Massachusetts, and is considered the first important American artist to show the influence of Romanticism in his work. ${ }^{17}$ However, like Eliot who was born in St Louis, Missouri but

\footnotetext{
${ }^{10}$ Eliot, Selected Prose, 16; Menand, 20.

${ }^{11}$ Eliot, To Criticize the Critic, 19.

${ }^{12} \mathrm{lbid}$.

13"Objective Correlative."

${ }^{14}$ A number of these essays had already appeared in The Sacred Wood (1920) such as "Hamlet and His Problems" and "Tradition And The Individual Talent".

${ }^{15}$ Eliot, Essays on Elizabethan Drama, vii.

${ }^{16}$ Ibid., vii-viii; see also Eliot "Letter from Eliot," 361.

${ }^{17}$ Chilvers.
} 
spent most of his life in England, Allston felt deep affinity with the culture of Europe, and studied painting in London and Italy. He was also on intimate terms with Coleridge, Wordsworth and Southey, founding figures in the English Romantic tradition. Allston wrote poetry, a novel in the Gothic style titled Monaldi (1841), and the first art treatise by an American, Lectures on Art, and Poems (1850), published posthumously. ${ }^{18}$ He was on the periphery of the Transcendentalists, having a review of his very successful 1839 exhibition published in the first issue of The Dial, in $1840 .{ }^{19}$

The obvious question is whether or to what extent Eliot read Allston's work, and it seems unlikely he had any direct knowledge of it. ${ }^{20}$ Eliot himself does not seem convinced that he arrived at the term via an encounter with Allston. The mildly incredulous tone of his reference in the 1956 preface, the suggestion that he was "told" about this link, and the fact that he misspells Allston's name, all suggest a general unfamiliarity with Allston. It is possible that Eliot was exposed to Allston's poetry during his undergraduate years at Harvard, but highly unlikely; Eliot studied literature and philosophy, and Allston was foremost a painter and not part of the canon of established poets and writers. Eliot wrote in 1946 that " $[u]$ ndergraduates at Harvard in my time read the English poets of the [18]90s who were dead: that was as near as we could get to any living tradition". ${ }^{21}$ Furthermore, under the influence of Irving Babbitt, a Harvard professor, Eliot turned firmly against Romanticism, espousing a lifelong commitment to Classicism. ${ }^{22}$ However, there is a distinct possibility that Eliot may have encountered Allston's work as a painter (and thus, possibly, knew of his treatise on art) through Edward Waldo Forbes, whose undergraduate Fine Arts course on Florentine painting Eliot took in 1910. Forbes, who was the grandson of Ralph Waldo Emerson, greatly admired the religious paintings of Allston, and we know that Eliot's studies under Forbes involved a special focus on religious art. ${ }^{23}$ Thus it is not unlikely that Eliot had heard of Allston and possibly knew of, or had seen his paintings. Eliot may also have encountered Allston indirectly; given the Unitarianism of his family in St Louis and the strength of the St Louis German Idealist and Transcendental philosophical tradition, there is a chance he may, in his childhood, have been exposed to Allston's ideas, or even the phrase "objective correlative". ${ }^{24}$ One scholar even argues that the idea of the "objective correlative" formed part of the intellectual vocabulary of thought in nineteenth-century New England, spreading beyond Allston to others. ${ }^{25}$ These links, though tenuous, make the intriguing, vestigial similarities between Eliot's use of "objective correlative" and Allston's less surprising, and suggest these similarities are worth investigating. Allston uses the term only once, in his Lectures on Art, and Poems. He discusses neoPlatonism arguing that it has aspects to it which are proto-phenomenological. The

\footnotetext{
${ }^{18}$ Ibid.

${ }^{19}$ Belasco; see also Wayne, 11-12.

${ }^{20}$ See Jain for an exhaustive overview of Eliot's Harvard education and influences. No mention of Allston is made in this book. From 1909-10 Eliot did complete a course on "Studies in the Poets of the Romantic Period" which was, no doubt, concentrated on the canon of mostly English authors (see Jain, 254).

${ }^{21}$ Eliot, Invention of the March Hare, 388. This statement originally appeared in the journal Poetry, in September 1946.

${ }^{22}$ Cuda, 4-5.

${ }^{23}$ Under Forbes's instruction Eliot made careful sketches of religious images from Italian art. Forbes later donated these sketches to Harvard, see Crawford. Eliot's grandfather William Greenleaf Eliot was a founding father of St Louis and noticed by Emerson; see Moody, 3.

${ }^{24}$ See Crawford for Eliot's Unitarian upbringing and his encounter with Forbes. See also Sigg, for another account of the household Unitarianism of Eliot's youth.

${ }^{25}$ Duffy.
} 
argument centres on the notion of our apprehension of "Ideas" which are "the highest or most perfect form in which any thing ... may exist in the mind". ${ }^{26}$ Objects become conscious to the mind, in the form of Ideas, for two reasons, either as "manifestations of objective realities" or as the "reflex product" of our mental constitution. ${ }^{27}$ For Allston the "external world" is manifest in the mind because the world is the mind's "objective correlative" ${ }^{28}$ The mind is pre-determined to be cognisant of "objective realities" because it possesses a "pre-existing idea [of them] in its living power". ${ }^{29}$ In addition, the proper end of this correlation is the experience of pleasure or satisfaction. ${ }^{30}$ The pre-determined correlation between the mind and external reality exists because both are located in the "unchangeable ground of Truth". ${ }^{31}$ Evidently, there is an underlying pseudo-Kantian position developed here; Allston wants to suggest that the mind is "pre-determined" to understand the world in an intelligible way. Thus categories of the mind cohere with outside phenomena. But Allston goes beyond Kant, aligning himself with Transcendentalism, and German Idealism generally, in that he argues that we are able to understand the world because both mind and reality are grounded in the divine, i.e., "unchangeable Truth", and so self-knowledge and self-development can enable this appreciation. ${ }^{32}$

When we compare Allston's use of the term with Eliot's, we can understand his incredulity at the suggestion that his "objective correlative" comes from Allston. Eliot's development of the term is very much literary and removed from the Transcendentalist heights of Allston's idealism. Yet there are similarities. Both argue that a mental state corresponds with external phenomena; and in both cases the proper alignment of the two results in some kind of experience: for Eliot, a genuine emotive audience response, and for Allston, a grasp of the divine order of things. Thus when the mind appreciates and understands reality in the fitting way, the experience that follows is one of truth, whether aesthetic or transcendent.

In addition to the term "objective correlative", Allston and Eliot also share some interesting biographic similarities which are suggestive, but tangential to this paper's main argument. Both came from a Unitarian background and studied at Harvard, Allston from 1796 to 1800, Eliot from 1906 to 1916 when he finished his doctoral thesis while already living in England. Both were successful poets, although Eliot was certainly more so than Allston. Both had a complex relationship with religious faith. In 1809 Allston married Ann Channing. Her untimely death in 1815, while they were living in London, affected him profoundly. Richard Henry Dana writes that after Allston's wife's death he developed an "undivided interest in spiritual relations" and received the rite of confirmation, becoming a devout adherent to Christian doctrine and discipline. ${ }^{33}$ Allston remained strongly Unitarian in his religious outlook, stating around 1830, "I am neither an Episcopalian nor a Congregationalist, I endeavour to be a Christian". ${ }^{44} \mathrm{He}$

\footnotetext{
${ }^{26}$ Allston, Lectures on Art, 3.

${ }^{27}$ Ibid., 3.

${ }^{28}$ Ibid., 16.

${ }^{29}$ Ibid.

${ }^{30}$ lbid.

${ }^{31}$ Ibid., 3.

${ }^{32}$ Wayne, viii.

${ }^{33}$ Dana, vi. Richard Henry Dana, Sr (1787-1879) was a minor novelist and poet. He was the first American critic of Romanticism. Dana is somewhat hagiographic in his description of Allston.

${ }^{34}$ Flagg, 245-6.
} 
notes in one of his letters written in 1830 that he was especially drawn to paint Biblical subjects and that the Scripture was a "source of inspiration" for his art. ${ }^{35}$ There is much evidence for this in his paintings, many of which depict religious events.

Eliot's conversion circumstances were somewhat different. ${ }^{36}$ When he very deliberately converted to Anglo-Catholicism in 1927, he was nearly estranged from his first wife, Vivienne Haigh-Wood. Their tumultuous and dysfunctional marriage was maintained with the barest façade of domesticity until 1932, when he went to America to deliver the Charles Eliot Norton poetry lectures at Harvard. When he returned to England in 1933 he separated from Vivienne and gradually immersed himself fully in the life of his parish, St Stephen's in Kensington, with a level of devotion akin to a tertiary member of a religious order. ${ }^{37}$ Like Allston, Eliot after his conversion was deeply inspired and influenced by his Christianity, producing in Four Quartets (1939-42) a poetic testament to his struggle with and redemption through faith. There is a remote possibility that Eliot may have been drawn to Allston's work if he learnt of the similarities between their life experiences. However, Eliot's essay on Hamlet, where the term "objective correlative" appears, was published in 1919, nearly a decade before he converted to Anglo-Catholicism. Thus, if Eliot had read Allston's letters, lectures or poems for some kind of solace during his own spiritual and domestic struggles, it would have been after the publication of the Hamlet essay, and thus of no consequence to this argument.

II.

Keeping in chronological order, as far as is possible, the next person to consider is the philosopher Francis Herbert Bradley (1846-1924), on whom Eliot wrote his PhD thesis. ${ }^{38}$ Bradley, based at Oxford University, was Britain's last significant neo-Hegelian, working in the tradition of German Idealism before it was eclipsed by the advent of modern logic and analytic philosophy. Eliot personally experienced this change in British philosophy, since he wrote on Bradley but then, for a time, came under the influence of Bertrand Russell. ${ }^{39}$ Eliot's debt to Bradley can be overstated; Anne C. Bolgan, for example, claims that

it is patently clear to anyone who has studied the work of both [Eliot and Bradley] that it is Bradley's mind that lies behind the structuring principles of Eliot's poetry, as well as every major theoretical concept appearing in his literary criticism. ${ }^{40}$

This is a claim far too general to be effectively substantiated, given the breadth of Eliot's learning. Bolgan's idea that Eliot's works show a "structuring principle" grounded in Bradley's Hegelian holism is suggestive, however. Simply put, holism is the belief that "the meaning of any thing is never autonomously given but is always a function of its place

\footnotetext{
${ }^{35}$ Ibid., 233.

${ }^{36}$ The question of whether Unitarianism is indeed a form of Christianity is historically complex. See Ahlstrom's masterful $A$ Religious History of the American People for a chronological overview of its development.

${ }^{37}$ Spurr, $115-16$.

${ }^{38}$ Eliot, Knowledge and Experience. See Mallinson for a sustained examination of Eliot's engagement with Bradley.

${ }^{39}$ Russell's influence on Eliot was formative and equivocal; see Shusterman "Eliot as Philosopher," 35-8. Some scholars have tried to argue, unconvincingly, that Eliot's "objective correlative" shows Russell's influence; see Green, 155; Shusterman, "Eliot and Logical Atomism"; also Skaff. Like Habib, 271, I think these positions overstated.

${ }^{40}$ Bolgan, 253. Bolgan was instrumental in the formal publication of Eliot's PhD in 1964.
} 
and interrelations with other things in a wider whole". ${ }^{41}$ This notion can be seen in Eliot's thinking about the nature of the literary canon, for example, in "Tradition and the Individual Talent" (1917) where he declares that "the historical sense compels a man to write not merely with his own generation in his bones, but with a feeling that the whole of the literature of Europe... has a simultaneous existence and composes a simultaneous order". 42

Given this deep sympathy of thought, a parallel between Eliot's "objective correlative" and aspects of Bradley's ideas would not be surprising. ${ }^{43}$ The term itself does not appear in Bradley's work, but we can discern clear lines of thought which echo it. For example, in Bradley's Essays on Truth and Reality (1914), parts of which Eliot quotes in his PhD thesis, Bradley writes that "every idea, even of failure, works successfully in producing a corresponding attitude or other change in my body or some part of it.... [T] o speak in general, an idea tends thus to express itself emotionally". ${ }^{4}$ This claim about the relational nature of ideas and their corresponding emotional effect on the body is very much in line with Eliot's own claims. Bradley goes on to write that in

any emotion one part of that emotion consists already of objects, of perceptions and ideas before my mind. And, the whole emotion being one, the special group of feeling is united with these objects before my mind, united with them integrally and directly.... There are features in feeling which already in a sense belong to and are one with their object, since the emotion contains and unites both its aspects. ${ }^{45}$

If we consider these ideas in light of Eliot's "objective correlative" there are similarities. While Bradley is concerned with the individual's own experience of ideas and their relation to emotion within an idealist framework, Eliot is concerned with how the artist is able to effectively convey her ideas (which are associated with a particular emotion) to the audience via the artwork. Bradley continues:

when a felt emotion is described, a man may feel that the description agrees or does not agree with an actual fact of which he is aware.... And it is, largely or mainly, because these suggestions are felt to be in unison or discord with something already felt as present, that they are accepted or rejected. ${ }^{46}$

Here again we can discern an echo in Eliot's work, particularly with regard to the failure of an artwork, such as Hamlet, which lacks an "objective correlative". The artist conveys an emotion through the artwork in order to evoke that emotional response in the audience. The "object" of that emotion, in Eliot's case the character Gertrude, fails to elicit the emotions of loathing and disgust, and thus there is no accord with the audience.

The last suggestive link to Bradley is a point Eliot develops in his own thesis, in agreement with a position developed by Bradley. ${ }^{47}$ Essentially Eliot claims that "emotion is really part of the object, and is ultimately just as objective". ${ }^{48}$ Emotional experiences are not pure abstractions, but psychical phenomena attached to physical structures. For

\footnotetext{
${ }^{41}$ Shusterman, "Eliot as Philosopher," 33.

${ }^{42}$ Eliot, Sacred Wood, 44.

${ }^{43}$ See Frank, 311-17, for a relatively unsuccessful attempt to locate this parallel.

${ }^{44}$ Bradley, Essays, 80, n.1.

${ }^{45}$ Ibid., 169. Eliot quotes this passage in his thesis. See Eliot, Knowledge and Experience, 24.

${ }^{46}$ Bradley, Essays on Truth and Reality, 185.

${ }^{47}$ Bradley, "Defence of Phenomenalism."

${ }^{48}$ Eliot, Knowledge and Experience, 80.
} 
example, to recall an object which is associated with pleasure is also to recall the experience of pleasure; the object and the emotion correlate.

III.

Another important source for Eliot's "objective correlative" comes from the work of the founder of phenomenology, Edmund Husserl (1859-1938). ${ }^{49}$ Again, the link can be overestimated; Sanford Schwartz, for example, claims that Eliot deliberately and consciously lifts the term from Husserl. ${ }^{50}$ Husserl does uses the phrase "objective correlate" [objektive Korrelat], which appears numerous times in his Logical Investigations (1900/1). Eliot read Husserl's Logical Investigations in its second, 1913 German edition; his annotated copy of Logische Untersuchungen is in the London library. ${ }^{51}$ Significantly this edition does not include the second part of the second volume, containing the Sixth Investigation, which was included in the first, 1900/1 edition and only again in the 1921 edition. ${ }^{52}$ Unable to revise the Sixth Investigation in 1913 as he intended Husserl withheld it, and sent only the first five investigations to press. These make up the two volumes of the book Eliot read. ${ }^{53}$ In the 1913 edition, without the Sixth Investigation, the term objektive Korrelat appears only four times, ${ }^{54}$ though in the Sixth Investigation, which Eliot did not have, it appears more frequently.

Eliot read the book while on a travelling fellowship to attend a summer programme for foreign students at Marburg University in the spring of 1914, five years before the publication of the Hamlet essay. At this period, all "student[s] of Idealism" at Harvard were expected to spend time at German universities. ${ }^{55} \mathrm{He}$ did not personally study with Husserl, who at this stage of his ascending career was still at the University of Göttingen. Eliot was in Germany only very briefly as the events of Sarajevo began to engulf Europe barely a month after he arrived. He left Germany on 3 August $1914 .^{56} \mathrm{He}$ started reading Logical Investigations while in Marburg, since he mentions the book's title in a letter (dated 25 July 1914) which he sent to Conrad Aiken, his closest early friend and fellow student at Harvard. ${ }^{57}$ That the letter is to a fellow student perhaps explains why Eliot refers to the book only by its German title, and in passing. $\mathrm{He}$ is more expansive about Husserl's work again in a letter dated 5 October 1914, addressed to his Harvard Professor of Philosophy, J. M. Woods. Eliot writes, "I have been plugging away at Hüsserl, and find it terribly hard, but very

\footnotetext{
${ }^{49}$ See Kumar for an interesting overview of Eliot's own phenomenology, as developed in his doctoral thesis, and its relation to Husserl.

${ }^{50}$ Schwartz, 9.

${ }^{51}$ The weathered edition of Eliot's Logische Untersuchungen was presented to the London Library by Mrs Michael Roberts in March 1952. On the title page is a faint, pencilled inscription: "T. S. Eliot, Marburg 1914".

${ }^{52}$ Moran, Ixvi, n.1.

${ }^{53}$ Ibid., xxxvill.

${ }^{54}$ In the 1913 edition the term objective Korrelat appears in volume 1, on page 134 as objektives Korrelat and on page 186, objektiven Korrelaten. In volume 2 it appears on page 25, objective Korrelat and on page 460, objektives Korrelat.

${ }^{55}$ Kirk, 29; Gordon, 95. Eliot had barely settled into life at Marburg when the First World War broke out and he left for Britain; see the introduction by Brooker and Schuchard in Eliot, Complete Prose, vol. 1, xli-xliii for an account of Eliot's transition from Marburg to London, and his being interviewed by the New York Times in this regard.

${ }^{56}$ Gordon, 96. Phenomenology had by 1914 attained a huge following in Germany and by the 1920s Husserl was the leading philosopher in Germany, until his work was eclipsed by that of his student, Martin Heidegger, with the publication of Being and Time (1927).

${ }^{57}$ Eliot, Letters, vol. 1, 49.
} 
interesting; and I like very much what I think I understand of it" ${ }^{58}$ This letter to Woods was written from Merton College, Oxford, showing that Eliot continued his study of Husserl after he left Germany.

In the English translation of Logical Investigations the phrase "objective correlate" often stands in for two distinct German terms used by Husserl, namely the more direct objektive Korrelat and also Gegenständlichkeit Korrelat. The latter term, particularly Gegenstand (object) is common in the Logische Untersuchungen. Eliot would also have been thoroughly familiar with it through the work of Alexius Meinong, known for his theory of objects (Gegenstandstheorie). In a letter written in 1956 Eliot indicates that at the same time he was reading Husserl he was also reading Meinong. ${ }^{59}$ He makes substantial references to Meinong's theory in numerous graduate essays and his $\mathrm{PhD}$ thesis particularly. ${ }^{60}$ In the English translation of the Logical Investigations the translator makes the point that "objectivity" would be the more direct translation of Gegenständlichkeit, but this term can imply that Husserl limits his understanding of objects only to physical things, whereas in fact he means to include "states of affairs, properties, and non-independent forms". ${ }^{61}$ Thus, as we will see from the discussion below, the term "objective" is preferred, and gives a better sense of what Husserl means.

In the First Investigation Husserl distinguishes between categories of meaning and objective categories, arguing that the latter are "objective correlates" of the former. ${ }^{62}$ His focus is on the nature of expression, and he writes that each expression

not merely says something, but says it of something: it not only has a meaning, but refers to certain objects.... But the object never coincides with the meaning. Both, of course, only pertain to an expression in virtue of the mental acts which give it sense. ${ }^{63}$

The language we use to speak about objects makes sense because there is an intentional, conscious relation between our expression about the object and the object itself. However, this relationship is in no way fixed, but only a correlation, which is dependent on the mental act which establishes the relation.

Husserl uses the example of different languages which express the same object, for example, "London”, “Londres”, “伦敦 (Lúndūn)” to show this. ${ }^{64}$ This phenomenon is significant for Husserl because it draws attention to an expression's

meaning and its power to direct itself as a name to this or that objective correlate ... an expression only refers to an objective correlate because it means something[;] it can be rightly said to signify or name the object through its meaning. ${ }^{65}$

\footnotetext{
${ }^{58}$ Ibid., vol. 1, 65. Eliot's own annotations in his copy of Logische Untersuchungen seem to confirm this difficulty. In volume 2 on pages 348-50 we see the words "Rubbish" and "What the devil does this mean?" added to the text.

${ }^{59}$ Eliot, Complete Prose, vol. 2, 731-2, n. 6.

${ }^{60}$ Three of Eliot's graduate essays Degrees of Reality, Suggestions toward a Theory of Objects and The Validity of Artificial Distinctions feature or allude to Meinong's theory of objects, and he is mentioned substantially in Eliot's PhD thesis. Also, in Schopenhauer's The World as Will and Representation, which Eliot studied at Harvard, the term "objective correlative" appears once as "objective Korrelat". See Schopenhauer, The World as Will, 216; Schopenhauer, Die Welt als Wille, 453. See also Virkar-Yates.

${ }^{61}$ Findlay, translator's note in Husserl, Logical Investigations, vol. 1, 321.

${ }^{62}$ Ibid., vol. 1, 196 onwards; for the German see Husserl, Logische Untersuchungen, Zweiter Band, 46. See also Steadman, 262.

${ }^{63}$ Husserl, Logical Investigations, vol. 1, 197.

${ }^{64}$ Ibid. See also Simons, 111.

${ }^{65}$ Husserl, Logical Investigations, vol. 1, 198.
} 
An expression is an act of meaning directed at something, but this does not fix the expression to the object. The context and inter-subjective nature of an expression are part of why it is meaningful, and these can change. However, these acts intend the "objective correlate of our act of meaning" to stand before us intuitively as the "very object we mean". 66

Aside from the philosophic discussion to explore Husserl's terminology there is some tantalising marginalia on page 25 of the second volume of Eliot's copy of Logische Untersuchungen where the term objektive Korrelat appears. Eliot has underlined some of the sentences, though not the term itself. Here, I quote each sentence entirely and indicate what is underlined:

A thing is only properly an indication if and where it in fact serves to indicate something to some thinking being. ${ }^{67}$... In these we discover as a common circumstance the fact that certain objects or states of affairs of whose reality someone has actual knowledge indicate to him the reality of certain other objects or states of affairs, in the sense that his belief in the reality of the one is experienced (though not at all evidently) as motivating a belief or surmise in the reality of the other. ${ }^{68}$... Plainly such a state of affairs amounts to just this: that certain things may or must exist, since other things have been given. This "since", taken as expressing an objective connection, is the objective correlate of "motivation" taken as a descriptively peculiar way of combining acts of judgement into a single act of judgement. $^{69}$

In this section Husserl discusses the relationship between signs, which are indicative of a state of affairs, and our judgement which results from making inferences from these signs. He argues that there is always a broader context of meaning, based on previous acts of judgement, which informs current judgements. However, this exists as a "unity of judgements", an "objective correlate" between previous judgements and the current one. ${ }^{70} \mathrm{We}$ can see that this is similar to what has already been discussed with regard to language, mental acts and their contexts. Our intentional relationship with the world is always already grounded in layers of meaning which inform, and are an inextricable part of whatever particular speech act or act of judgement we are attentive to in the moment.

The term is significant at two further points in Husserl's book. In the First Investigation it appears again at a later stage, used in much the same way as described only now Husserl is discussing the nature of "pure logic". ${ }^{71}$ Pure logic is arrived at through the phenomenological reduction of "concepts, judgements, and syllogisms" to their "ideal unities". This reduction is achieved through detaching the "ideal essence of meanings" from their "psychological and grammatical connections", essentially disengaging these essences

\footnotetext{
${ }^{66}$ Ibid., 200.

${ }^{67}$ Husserl, Logical Investigations, vol. 1, 184. This is underlined horizontally. The underlined German is "einem denkenden Wesen"; Husserl, Logische Untersuchungen, Zweiter Band, 25.

${ }^{68}$ Husserl, Logical Investigations, vol. 1, 184. This section is highlighted by a vertical line in the margin. In the German version this section is not italicised. The German is "den Umstand, daß irgendwelche Gegenstände oder Sachverhalte, von deren Bestand jemand aktuelle Kenntnis hat, ihm den Bestand gewisser anderer Gegenstände oder Sachverhalte in dem Sinne anzeigen, daß die Überzeugung von dem Sein der einen von ihm als Motiv (und zwar als ein nichteinsichtiges Motiv) erlebt wird für die Überzeugung oder Vermutung vom Sein der anderen"; Husserl, Logische Untersuchungen, Zweiter Band, 25.

${ }^{69}$ Husserl, Logical Investigations, vol. 1, 184. This is underlined horizontally. The underlined German is "Dieses „well", als Ausdruck eines sachlichen Zusammenhanges aufgefaßt"; Husserl, Logische Untersuchungen, Zweiter Band, 25.

${ }^{70}$ Husserl, Logical Investigations, vol. 1, 184.

${ }^{71}$ Ibid., 224. This English edition is published in two separate volumes. Part of volume 2, which is where this discussed material comes from, is included in the first volume.
} 
from the "objective correlates that they mean". ${ }^{72}$ This ideal domain is that of pure logic, the nomological science of which modern symbolic logic is an example. The final substantive discussion of "objective correlate" occurs in the Sixth Investigation, which was not included in Eliot's edition. An important section here is $\$ 43$ which is titled “The Objective Correlates of Categorical Forms Are Not 'Real' Moments". ${ }^{73}$ Husserl makes a technical philosophical point about Kantian categorical forms such as quantity and quality. Essentially he argues that forms such as these, like symbolic logic, have no "objective correlates" themselves in terms of objects occurring in the "real", i.e. external world. For example, though the quality of smoothness or abrasiveness is part of an object such as a wooden surface, "smoothness" itself has no objective correlate as such. ${ }^{74}$

From this initial discussion it is clear that there are some superficial similarities but perhaps more importantly significant differences between Eliot's "objective correlative" and Husserl's "objective correlate". There is certainly a level of sophistication and detail in Husserl's account which is lacking in Eliot's. For Husserl, meaning is possible because of mental acts and their contexts which establish an intentional link between an expression and its object, thus allowing them to "correlate" meaningfully. On this level the relationship is "objective" in a scientific sense because the correlation is always between mental acts and their contexts. For a phenomenologist, every mind which thinks, thinks in this direct, intentional way. When we interrogate this fundamental orientation we have with the world, what is revealed is this phenomenological arrangement. On another level, what is also revealed is our own historicity and worldhood, what Martin Heidegger calls "thrownness" (Geworfenheit), which is subjective and seemingly arbitrary. We find ourselves already in meaning, in language and in a context which makes the world cohere and orientates us in it. Husserl shows that language allows us to direct and articulate our conscious thoughts to the objects around us such that there is a correlation between what is thought and what is meant. Language is the interpretive "glue" which sticks the mental act and the physical phenomenon together. But the language is itself contextual and forms part of a particular worldview and worldhood.

Eliot also argues for a correlation, but in a less rigorous way than Husserl. In his $\mathrm{PhD}$ Eliot holds that emotions cohere in objects and that if the artist arranges these objects properly she will evoke the desired response in the audience. However, these claims are more ambiguous because of their uninterrogated naive idealism. Eliot's "objective correlative" seems to imply, like Husserl to some extent, that "objective" should be understood in its proper, scientific sense, suggesting that there are underlying, universal objects which can evoke the desired emotional response from an audience, or fail to. But, unlike Husserl, Eliot does not develop this position at all, which is deeply problematic because it overlooks the hermeneutic dimension that plays a role in all human experience, particularly in the appreciation and interpretation of art. In addition, Eliot's term commits the intentional fallacy, for it assumes that authorial intent and audience reception should be directly connected via the artwork-that there should, in fact, be an "objective" correlation.

Yet, and perhaps this shows up why Eliot was more an artist than philosopher, if we read his famous essay "Tradition and the Individual Talent" written in 1917, two years

\footnotetext{
${ }^{72}$ Husserl, Logical Investigations, vol. 1, 224.

${ }^{73}$ Ibid., vol. 2, 277.

${ }^{74}$ Ibid., vol. 2, 277-8.
} 
before the Hamlet essay, he seems to contradict what he claims in $1919 .^{75}$ In the earlier essay he writes that the "progress of the artist is a continual self-sacrifice, a continual extinction of personality ... to something which is more valuable". ${ }^{76}$ The creation of the artist is a process of "depersonalization", "an escape from personality"; "the more perfect the artist, the more completely separate in him will be the man who suffers and the mind which creates". ${ }^{77}$ Here Eliot argues that the creation of the artwork ultimately exists independently of the personality of its creator, a central tenet of New Criticism, of which he is considered a founder. But in the Hamlet essay he seems to hold the artist personally responsible for her ability to evoke the proper emotive response in the audience, which, as we shall see below, is a position shared with Bergson.

In spite of the somewhat "unwieldy" nature of Eliot's early criticism it is worth noting the general currency these ideas had. For example, Heidegger, a direct contemporary of Eliot, wrote in 1935 that "in great art the artist remains something inconsequential in comparison with the work - almost like a passageway which, in the creative process, destroys itself for the sake of the coming forth of the work" ${ }^{78}$ He echoes these sentiments again in 1955, writing about the composer Conradin Kreutzer, that the artist's presence in the work is the "only true presence. The greater the master, the more completely his person vanishes behind his work". ${ }^{79}$ These claims resonate with Eliot's own claims about artist depersonalisation.

Also suggestive, although tangential to a discussion of Eliot, is the fact that the term "objective correlate" (Gegenständliche Korrelat) appears in Heidegger's work. When Husserl transferred to the University of Freiburg from Göttingen in 1916, Heidegger worked as his assistant from 1919 to 1923 before transferring to Marburg. It is perhaps no surprise then that ideas reminiscent of the "objective correlate" appear in Heidegger's early work. Heidegger uses the term "objective correlate" in a strongly critical review essay of Karl Jaspers's recently published Psychology of Worldviews (1919) ${ }^{80}$ This essay, though written between 1919 and 1920, was only published in 1972 after a copy of it was found among Jaspers's papers after his death in 1969. Heidegger had written the draft and sent it to Jaspers, Husserl and Heinrich Rickert in 1921 but, for unknown reasons, decided not to publish it at that time. ${ }^{81}$

In the essay Heidegger criticises Jaspers's "preconception" that the subject, in order to understand the "object" or "whole" of reality, requires a "theoretical, observational attitude" as a "correlative" way of understanding it. ${ }^{82}$ For Heidegger this preconception implies that the "fundamental characteristic of the objective correlate of this theoretical attitude lies in the fact that it is an objective thing" ${ }^{83}$ This is precisely the problem for Heidegger: Jaspers's initial approach to psychical life is based on a preconception about the nature of psychical life which already forms part of the "objective" and "primordial"

\footnotetext{
${ }^{75}$ It is somewhat ironic that both these essays appeared in print in the same year, 1919, even though they appear to contradict one another. "Tradition and the Individual Talent" was published in The Egoist, a London literary review; see Murphy, 405.

${ }^{76}$ Eliot, Sacred Wood, 47.

${ }^{77}$ Ibid., 47-8, 52.

${ }^{78}$ Heidegger, Off the Beaten Track, 19.

${ }^{79}$ Heidegger, Discourse on Thinking, 44.

${ }^{80}$ Heidegger, "Comments."

${ }^{81}$ Krell, 11.

${ }^{82}$ Heidegger, "Comments," 18.

${ }^{83} \mathrm{Ibid}$. The German sentence is "Das besagt, das gegenständliche Korrelat solcher Einstellung hat den Grundgegenstandscharakter der objektiven Sache"; Heidegger, Gesamtausgabe, Band 9, 21.
} 
observations he wants to make. ${ }^{84}$ Heidegger questions whether this preconception "enjoys the level of primordiality that is claimed for it" and whether the motives which drive Jaspers along his interrogative path are made evident. ${ }^{85}$ For Heidegger clearly they are not. Jaspers believes that his method, which he calls "mere observation", can observe "simply that which exists and is there for us so far in human experience. ${ }^{86}$ But this ignores the historicised nature of all observation, the fact that "our observing of phenomena of life is historical, insofar as it must inevitably be interpretive". ${ }^{87}$ In order to understand the methodology that observation entails I must interpret its nature within the context where it occurs. As Heidegger's Being and Time puts it, any "interpretation which is to contribute understanding must already have understood what is to be interpreted" ${ }^{88}$ Thus the prejudices and presuppositions which direct observation must be examined and interpreted, and this is what Jaspers neglects to consider.

Heidegger's criticism of Jaspers is helpful here because we see the same kind of "blindness" in Eliot's Hamlet essay, which assumes a straightforward, unexamined and supposedly "objective" correlation between the intentions of the artist and the reception of the audience. Heidegger concludes his essay by arguing that "mere observation" must evolve "into an 'infinite process' of radical questioning that always includes itself in its questions and preserves itself in them" ${ }^{89}$ Essentially he requires constant cognisance of the hermeneutic circle which, if ignored, makes "mere observation" a phenomenologically naive and misguided process - a criticism as valid for Eliot as it is for Jaspers. As an aside, Eliot does mention Heidegger's name a few times in his letters and in The Criterion in 1932 , but that is unfortunately the extent of their engagement. ${ }^{90}$

IV.

Another philosopher who Eliot not only read, but whose lectures he also attended at the Collège de France for two months during his 1910-11 sojourn in Paris was Henri Bergson (1859-1941)..$^{91}$ Eliot even admitted to a "temporary conversion to Bergsonism", 92 though after returning to Harvard he wrote an essay as part of his doctoral work specifically criticising what he saw as inconsistencies in Bergson's philosophy. ${ }^{93}$ This graduate essay,

\footnotetext{
${ }^{84}$ Heidegger, "Comments," 7.

${ }^{85}$ Ibid., 19.

${ }^{86}$ Ibid., 32. Heidegger is quoting Jaspers here.

${ }^{87}$ Heidegger, "Comments," 33.

${ }^{88}$ Heidegger, Being and Time, 194.

${ }^{89}$ Heidegger, "Comments," 37.

${ }^{90}$ Eliot, "Commentary," 73. In 1930, in a letter to Erich Alport, Eliot writes "I should very much like also to read something of Heidegger. During the month of August 1914, I sat in Marburg, smoking cigars and reading the works of Husserl, and I still know just enough about the subject to be extremely interested in the work of a disciple." In 1931, in a letter to Stephen Spender, Eliot writes "Have you found anything worth reading? There is a philosopher named Martin Heidegger-a disciple of the great Husserl, who really is good, I think, though far from lucid-whom I have been agonising over." See Eliot, Letters, vol. 5, 228, 529. The phrasing is ambiguous, leaving us to guess whether Eliot means agonising over whether or not to read Heidegger, or instead, agonising over Being and Time itself. Sein und Zeit was published in 1927 in Husserl's Jahrbuch and established Heidegger's international reputation as a philosopher, solidifying his early academic career. While Heidegger had published some other texts around the time Eliot was writing these letters it seems likely that if he did read anything by Heidegger it would have been Sein und Zeit.

${ }^{91}$ See Hargrove for an account of what Eliot's experience of Paris would have been like.

${ }^{92}$ Eliot, Sermon, 5.

${ }^{93}$ Dating this manuscript on Bergson has proved puzzling for Eliot scholars, though most agree that it was either written in 1913 or 1914, after Eliot had returned to Harvard to write his PhD. See Habib, 61ff. See also Le Brun; Eliot, Complete Prose, vol. 1, 88, n. 2 .
} 
Inconsistencies in Bergson's Idealism and another, The Relationship between Politics and Metaphysics, both delivered by Eliot to the Harvard Philosophical Club around 191314, are critical of Bergson. ${ }^{94}$ Evident from these essays, particularly the first, is Eliot's strong familiarity with Bergson's major works. ${ }^{95}$ While Bergson does not explicitly use the term "objective correlate", he alludes to ideas which clearly imply a sense of it. These are developed in more of an aesthetic than a philosophical sense in his Time and Free Will: An Essay on the Immediate Data of Consciousness. ${ }^{96}$ Bergson argues that the "charm of poetry" is derived from the poet in "whom feelings develop into images, and the images themselves into words". When we, as readers, experience these images in the poetry, we in turn experience the feelings that are the "emotional equivalents" of the ones experienced by the poet; to paraphrase Bergson, we think and see with the poet. ${ }^{97} \mathrm{He}$ goes on to write that the aim of art is to impress feelings on us, rather than to induce us to express them: the artwork "suggests them to us, and willingly dispenses with the imitation of nature when it finds some more efficacious means". ${ }^{98}$

This aesthetic emotion is experienced with varying degrees of intensity. It may scarcely distract us from our immediate involvement with the world; it may briefly draw our attention away from that involvement; or, most intensely, it may engross us and "monopolize our souls". 99 The "merit" of a work of art is measured by the intensity and richness of the aesthetic emotion it evokes. Bergson connects this emotion with the artist herself, stating that the feelings and thoughts communicated to us by the artwork convey in them a history of the artist, her lifeworld and experiences. Thus the aim of the artist is to enable us to experience the complexity of emotion which she "cannot make us understand". ${ }^{100}$ The artist will attempt to communicate these indefinable psychological states by capturing them in the artwork: "the richer in ideas and the more pregnant with sensation and emotions is the feeling within whose limits the artist has brought us, the deeper and the higher shall we find the beauty thus expressed". ${ }^{101}$ The successful experience of art is meant to "put to sleep" the resistant powers of our own personality, and bring us to a "state of perfect responsiveness" such that we can sympathise with the feeling expressed in the artwork. Exactly how and why some artwork can achieve this intensity of experience and others not is underdeveloped and somewhat obtuse in Bergson. Essentially the purpose of art is to express beauty, and the essence of the beautiful "remains unexplained". ${ }^{102} \mathrm{He}$ suggests that we "instinctively distinguish degrees of depth" in our encounter with the artwork, reflected in the history of the artist. ${ }^{103}$

Examining Eliot's graduate essay Inconsistencies in Bergson's Idealism shows that he was explicitly attentive to these ideas of aesthetic intensity and their communicability in

\footnotetext{
${ }^{94}$ Eliot, Complete Prose, vol. 1, 67-105. For an overview of what these graduate essays discuss see Brooker and Schuchard's introduction in Eliot, Complete Prose, vol. 1, xxxvii-xxxviii, xl-xli.

${ }^{95}$ Eliot references Bergson's L'Évolution Créatice (1907) [Creative Evolution], Essai sur les Données Immédiates de la Conscience (1889) [Time and Free Will: An Essay on the Immediate Data of Consciousness] (1889) and Matière et Mémoire: Essai sur la Relation du Corps a l'Esprit (1896) [Matter and Memory].

${ }^{96}$ Eliot obviously uses the original French version. The first English translation appeared in 1910.

${ }^{97}$ Habib, 45. See Bergson, 15.

${ }^{98}$ Bergson, 17.

${ }^{99}$ Ibid., 17

${ }^{100}$ Ibid., 18.

${ }^{101} \mathrm{lbid}$.

${ }^{102}$ Ibid., 14.

${ }^{103}$ Ibid., 17. My emphasis.
} 
Time and Free Will, referencing them closely and describing one passage by Bergson, in this context, as "remarkable". ${ }^{104}$ Evidently there are strong parallels that Eliot's "objective correlative" shares with Bergson's aesthetic theory of emotion. Both suggest that in the encounter with the successful artwork an "emotional equivalence" will emerge which resonates between the artist and audience. This allows a communication to occur which, in its fullness, has the capacity to "monopolize our soul". Eliot suggests that Macbeth offers such an equivalence, because the artwork is able to successfully convey the emotions of guilt and horror which Shakespeare intends. Bergson is also explicit about the role of the artist; her lifeworld and experience are encapsulated and communicated in the artwork. While Eliot is not as explicit about this dimension in his theory of the "objective correlative", it is implied.

\section{V.}

In conclusion it is evident that there are many lines of influence which can be drawn to Eliot's "objective correlative". However, there is no single, direct source for the notion. The term is his own, but also fits within the broader currents of thought that surrounded him, and to which he was exposed, most notably the remnants of Hegelian idealism. For the idealist, mind and reality cohere. Rationality allows us to uncover and discern its truth, particularly in the encounter with the artwork. The successful artwork is able to distil some aspects of this truth, which the mind, as Bergson suggests, is "instinctively" able to comprehend because it is attuned to recognise and appreciate beauty when it encounters it.

We cannot discount entirely the influence, even unconscious, of the work of Washington Allston, given the Unitarianism of Eliot's youth and its entanglement with Transcendentalism. Nor can we discount the influence Forbes may have had on Eliot through his familial relationship to Emerson, and the possibility that he may have introduced Eliot to Allston's painting, and even mentioned his aesthetic theory. Thus, in spite of Eliot's protestation regarding his original claim to the term, perhaps its embryonic form had already implanted itself in his early intellectual development.

While it is convenient to argue that the term's actual inspiration was Husserl and that Eliot merely appropriated it, this claim is not so straightforward to substantiate, especially given the edition of Logical Investigations which Eliot read. One could even go so far as to argue that Eliot's 1956 preface, where he mentions somewhat incredulously Allston's claim to the term, provided an ideal opportunity to acknowledge Husserl's influence. The fact that he did not do so suggests that it did not occur to him, because he probably had no recollection that the term was Husserl's, and that he might have encountered a German version of it first in Logical Investigations. Also, it is evident from the above discussion that Husserl is using the term in a complex phenomenological sense, whereas Eliot's use is much less developed, and closer to idealism. The two conceptions are different to such an extent that if Eliot did appropriate the term from Husserl (which we cannot entirely discount given the temporal proximity of his reading and annotating Logical Investigations and writing "Hamlet and His Problems") then it was only as an unconscious borrowing of the expression itself, and not the particular way Husserl develops it. However, it seems likely that the confluence of Husserl and Meinong, and their

${ }^{104}$ Eliot, Complete Prose, vol. 1, 67-8. 
widespread use of the term Gegenstand in its various philosophic iterations, must have played some role in Eliot's development of his own term.

This leaves us to consider Bergson and Bradley, who both provide ideas which, I think, strongly and evidently influenced Eliot's development of his "objective correlative". We know that Eliot wrote critically on Bergson as part of his PhD studies, around 1913-14, specifically mentioning his aesthetic emotive theory, which is very similar to Eliot's own. Bergson's claim for an "emotional equivalence" communicated from the artist to the audience corresponds very strongly to Eliot's own claims for an "exact equivalence", a "complete adequacy of the external to the emotion". In the case of Bradley we can also discern clear lines of thought which reverberate through Eliot's work, both in his thesis and his literary theory. Bradley's claims, that every idea produces a corresponding emotion, and that emotions are themselves indelibly linked to objects, are beliefs central to Eliot's own "objective correlative". Furthermore, these ideas are quoted by Eliot in his own $\mathrm{PhD}$ thesis, in agreement with Bradley, which strongly suggests that Eliot valued them and considered them worth reflecting on. Eliot goes so far as to write that "emotion is really part of the object", a philosophical claim which forms the basis for his aesthetic theory in "Hamlet and His Problems". Some years later, in his 1961 address "To Criticize the Critic", Eliot states that "I have written best about writers who have influenced my own poetry ... I include F. H. Bradley, whose work-I might say whose personality as manifested in his works-affected me profoundly". ${ }^{105}$ I believe we have licence here to go beyond Eliot's poetry, and to include his criticism in this claim.

What is evident is that, while there is no clear, direct source for Eliot's term it emerged in the mind of someone who was attuned to and perceptive of the significant philosophical and aesthetic ideas of his time, and who drew from his considerable and varied intellectual experience in developing his literary criticism. He was aware of the ongoing conversation about the nature of objects and how we experience them, but his conception of the "objective correlative" owes more to the older idealist tradition, and Bergson's aesthetic development of it, than to the fully phenomenological approach seen in Husserl and Heidegger. The term remains an important feature of early twentieth-century literary theory and its influence and importance, though diminished in terms of application, remain significant as an encapsulation of, in the words of Eliot, "the mind of my generation". ${ }^{106}$

\section{Disclosure Statement}

No potential conflict of interest was reported by the author.

\section{Acknowledgements}

I would like to acknowledge the immeasurable assistance of Maria Prozesky for her editing and insightful comments, and the anonymous reviewers for their helpful contributions. I would also like to thank Samantha Gibson and the London library for assistance with Eliot's copy of Husserl's Logische Untersuchungen, and Ernst Wolff for help with aspects of the German translation of this text. Lastly, I would like to thank Catherine Botha, Thaddeus Metz and the Philosophy Department

\footnotetext{
${ }^{105}$ Eliot, To Criticize the Critic, 20.

${ }^{106}$ Ibid., 19.
} 
at the University of Johannesburg for the postdoctoral fellowship which enabled the completion of this piece.

\section{ORCID}

Dominic Griffiths (D) http://orcid.org/0000-0002-6773-7184

\section{References}

Ahlstrom, Sydney. A Religious History of the American People. New Haven: Yale University Press, 2004.

Allston, Washington. Lectures on Art, and Poems. New York: Baker and Scribner, 1850.

- Monaldi. London: Edward Moxon, 1842.

Belasco, Susan. "The Dial." In The Oxford Handbook of Transcendentalism, edited by Sandra Harbert Petrulionis, Laura Dassow Walls, and Joel Myerson. Oxford: Oxford University Press, 2012. [cited 24 October 2012]. Available from www.oxfordhandbooks.com/view/10.1093/ oxfordhb/9780195331035.001.0001/oxfordhb-9780195331035-e-26?rskey=hz18IR\&result=1.

Bergson, Henri. Time and Free Will: An Essay on the Immediate Data of Consciousness. Translated by F. L. Pogson. London: George Allen \& Unwin, 1950.

Bolgan, Anne. "The Philosophy of Bradley and the Mind and Art of Eliot." In English Literature and British Philosophy, edited by S. P. Rosenbaum. Chicago: University of Chicago Press, 1971.

Bradley, F. H. "A Defence of Phenomenalism in Psychology." Mind IX (1900): 26-45.

- Essays on Truth and Reality. Oxford: Clarendon Press, 1962.

Chilvers, Ian. "Allston, Washington." In The Oxford Dictionary of Art and Artists. Oxford: Oxford University Press, 2009. [cited 24 October 2012]. Available from www.oxfordreference.com. ezproxy.auckland.ac.nz/view/10.1093/acref/9780199532940.01.0001/acref-9780199532940-e-54.

Cowley, V. J. E. “A Source for T. S. Eliot's 'Objective Correlative'.” The Review of English Studies 26, no. 103 (1975): 320-1.

Crawford, Robert. Young Eliot. New York: Farrar, Straus and Giroux, 2015.

Cuda, Anthony. "The Poet and the Pressure Chamber: Eliot's Life." In A Companion to T. S. Eliot, edited by David E. Chinitz. Malden: Wiley-Blackwell, 2009.

Dana, Richard Henry. Introduction to Lectures on Art, and Poems, by Washington Allston. New York: Baker and Scribner, 1850.

DeLaura, David. "Pater and Eliot: The Origin of the 'Objective Correlative'." Modern Language Quarterly 26 (1965): 426-31.

Di Pasquale, Pasquale. "Coleridge's Framework of Objectivity and Eliot's Objective Correlative." The Journal of Aesthetics and Art Criticism 26, no. 4 (1968): 489-500.

Duffy, John. “T. S. Eliot's Objective Correlative: A New England Commonplace.” The New England Quarterly 42, no. 1 (1969): 108-15.

Eliot, T. S. “A Commentary.” The Criterion 12 (1967): 73.

- The Complete Prose of T. S. Eliot: The Critical Edition. Vol. 1. Apprentice Years 1905-1918. Edited by Jewel Spears Brooker and Ronald Schuchard. Baltimore: Johns Hopkins University Press, 2014.

- The Complete Prose of T. S. Eliot: The Critical Edition. Vol. 2, The Perfect Critic, 1919-1926. Edited by Anthony Cuda and Ronald Schuchard. Baltimore: John Hopkins University Press, 2014.

- Elizabethan Essays. London: Faber and Faber, 1934.

—. Essays on Elizabethan Drama. New York: Harvest Books, 1956.

"Hamlet and His Problems." Athenaeum 4665 (26 September, 1919).

Invention of the March Hare: Poems 1909-1917. Edited by Christopher Ricks. San Diego: Harcourt Brace, 1998. 1964. 
_. "A Letter from Eliot," The New Statesman, 5 March 1965.

- The Letters of T. S. Eliot. Vol. 1, 1898-1922. Edited by Valerie Eliot and Hugh Haughton. London: Faber and Faber, 2009.

- The Letters of T. S. Eliot. Vol. 5, 1930-1931. Edited by Valerie Eliot and John Haffenden. New Haven: Yale, 2015.

- The Sacred Wood: Essays on Poetry and Criticism. New York: Alfred A. Knopf, 1921.

- Selected Essays. New York: Harcourt Brace, 1932.

- Selected Prose of T. S. Eliot. San Diego: Harvest Books, 1975.

- A Sermon Preached in Magdalene College Chapel. Cambridge: Cambridge University Press, 1948.

- To Criticize the Critic and Other Writings. Lincoln: University of Nebraska Press, 1991.

Flagg, J. B. The Life and Letters of Washington Allston. New York: Charles Scribner's Sons, 1969.

Frank, Armin Paul. "T. S. Eliot's Objective Correlative and the Philosophy of F. H. Bradley." The Journal of Aesthetics and Art Criticism 30, no. 3 (1972): 311-17.

Gallup, Donald. T. S. Eliot. A Bibliography. London: Faber and Faber, 1952.

Green, Keith. Bertrand Russell: Language and Linguistic Theory. London: Continuum, 2007.

Greenburg, Bradley. “T. S. Eliot's Impudence: Hamlet, Objective Correlative, and Formulation.” Criticism 49, no. 2 (2007): 215-39.

Gordon, Lyndall. T. S. Eliot: An Imperfect Life. New York: W. W. Norton, 2000.

Habib, M. A. R. The Early T. S. Eliot and Western Philosophy. Cambridge: Cambridge University Press, 2008.

Hargrove, Nancy. T. S. Eliot's Parisian Year. Gainesville: University Press of Florida, 2009.

Hartman, Charles. Free Verse: An Essay on Prosody. Princeton: Princeton Press, 1980.

Heidegger, Martin. Being and Time. Translated by John Macquarrie and Edward Robinson. Malden: Blackwell, 1962.

- "Comments on Karl Jaspers's Psychology of Worldviews." In Pathmarks, edited by William McNeill, translated by John van Buren. Cambridge: Cambridge University Press, 1998.

- Discourse on Thinking. Translated by John Anderson and Hans Freund. New York: Harper \& Row, 1969.

- Gesamtausgabe, Band 9: Wegmarken. Frankfurt am Main: Vittorio Klostermann, 1976.

- Off the Beaten Track. Edited and translated by Julian Young and Kenneth Haynes. Cambridge: Cambridge University Press, 2000.

Husserl, Edmund. Logical Investigations. 2 vols. Edited by Dermot Moran, translated by J. N. Findlay. London: Routledge, 2001.

- Logische Untersuchungen, Zweiter Band. Halle: Max Niemeyer, 1913.

Jain, Manju. T. S. Eliot and American Philosophy: The Harvard Years. Cambridge: Cambridge University Press, 2004.

Kermode, Frank. Introduction to Selected Prose of T. S. Eliot. San Diego: Harvest Books, 1975.

Kirk, Russell. Eliot and His Age: T. S. Eliot's Moral Imagination in the Twentieth Century. Wilmington: ISI Books, 2008.

Krell, David Ferrell. Intimations of Mortality: Time, Truth, and Finitude in Heidegger's Thinking of Being. University Park: Pennsylvania State University Press, 1986.

Kumar, Jitendra. "Consciousness and Its Correlatives: Eliot and Husserl." Philosophy and Phenomenological Research 28, no. 3 (1968): 332-52.

Lees, F. N. “T. S. Eliot and Nietzsche.” Notes \& Queries 11 (1964): 386-7.

Le Brun, Philip. “T. S. Eliot and Henri Bergson.” The Review of English Studies 18, no. 70 (1967): 149-61.

Mallinson, Jane. T. S. Eliot's Interpretation of F. H. Bradley. Dordrecht: Springer, 2002.

McElderry, B. R. "Santayana and Eliot's Objective Correlative." Boston University Studies in English 3 (1957): 179-81.

Menand, Louis. “T. S. Eliot.” In The Cambridge History of Literary Criticism, vol. 7, Modernism and the New Criticism, edited by Walton Litz, Louis Menand, and Lawrence Rainey. Cambridge: Cambridge University Press, 2008. 
Moody, A. David. Tracing T. S. Eliot's Spirit: Essays on his Poetry and Thought. Cambridge: Cambridge University Press, 1996.

Moran, Dermot. Introduction to Logical Investigations, vol. 1 by Edmund Husserl, edited by Dermot Moran, translated by J. N. Findlay. London: Routledge, 2001.

Murphy, Russell Eliot. Critical Companion to T. S. Eliot: A Literary Reference to His Life and Works. New York: Facts On File, 2007.

“Objective Correlative." The Literary Encyclopedia. [cited 13 August 2014]. Available from www. litencyc.com.

Sayeau, Michael. Against the Event. The Everyday and Evolution of Modernist Narrative. Oxford: Oxford University Press, 2013.

Schopenhauer, Arthur. Die Welt als Wille und Vorstellung. Berlin: Digitale Bibliothek Band 2: Philosophie, 1859.

- The World as Will and Representation. Translated by E. F. Payne. New York: Dover, 1966. Schwartz, Sanford. The Matrix of Modernism: Pound, Eliot and Early Twentieth-Century Thought. Princeton: Princeton University Press, 1985.

Shusterman, Richard. "Eliot and Logical Atomism." English Literary History 49, no. 1 (1982):16478.

_ . "Eliot as Philosopher." In The Cambridge Companion to T. S. Eliot, edited by A. D. Moody. Cambridge: Cambridge University Press, 1994.

Sigg, Eric. The American T. S. Eliot: A Study of the Early Writings. Cambridge: Cambridge University Press, 1989.

Simons, Peter. "Meaning and Language." In The Cambridge Companion to Husserl, edited by Barry Smith and David Smith. Cambridge: Cambridge University Press, 1999.

Skaff, William. The Philosophy of T. S. Eliot: From Skepticism to a Surrealist Poetic, 1909-1927. Philadelphia: University of Pennsylvania Press, 1986.

Spurr, Barry. "Anglo-Catholic in Religion." T. S. Eliot and Christianity. Cambridge: Lutterworth, 2010.

Steadman, J. M. "Eliot and Husserl: The Origin of the 'Objective Correlative'." Notes \& Queries 203 (1958): 261-2.

Virkar-Yates, Aakanksha. "An Objective Chemistry: What T. S. Eliot Borrowed from Schopenhauer." Philosophy and Literature 39, no. 2 (2015): 527-37.

Wayne, Tiffany. Encyclopedia of Transcendentalism. New York: Infobase, 2006.

Wood, Michael. “The Struggles of T. S. Eliot,” The New York Review of Books, 13 May 1976. [cited 22 March 2016]. Available from www.nybooks.com/articles/1976/05/13/the-struggles-of-tseliot/. 